\begin{tabular}{|l|l|l|l|l|}
\hline Cuadernos de Investigación Geográfica & 2001 & N$^{\circ} 27$ & pp. 95-105 & ISSN 0211-6820 \\
\hline
\end{tabular}

(c) Universidad de La Rioja

\title{
THE WATER BALANCE OF DIFFERENT SOILS ON ABANDONED FIELDS ALONG A TRANSECT FROM THE HIGH PYRENEES TO THE CENTRAL EBRO BASIN
}

\author{
TILMANN SAUER \\ JOHANNES B. RIES
}

\begin{abstract}
Johann Wolfgang Goethe University, Institute of Physical Geography, Senckenberganlage 36, D-60325 Frankfurt am Main, Germany t.sauer@em.uni-frankfurt.de / j.b.ries@em.uni-frankfurt.de
\end{abstract}

ABSTRACT: The water storage capacity of 10 typical soils on abando ned fields in five test areas along a transect from the High Pyrenees to the Central Ebro Basin is related to precipitation and potential evapotranspi ration. The annual precipitation increases from $300 \mathrm{~mm}$ in the Central Ebro Depression to $1700 \mathrm{~mm}$ in the subalpine area, the potential evapo transpiration decreases from $920 \mathrm{~mm}$ to $650 \mathrm{~mm}$. However in the High Pyrenees, months with a negative water balance are frequent. For a period of 6 years (1994-1999) the potential soil water balance was calculated on the base of physical soil properties and climatic data in daily intervals. The results show several periods with a very low content of plant available water in all test areas. They last for up to 8 months in the Central Ebro Basin and 2 weeks in the high mountain region. Beside grazing and soil erosion, the limitation of plant available water is a major reason for a slow vegetation succession on abandoned fields.

RESUMEN: La capacidad de almacenamiento de agua en 10 suelos de campos abandonados en un transecto de los Pirineos a la Depresión del Ebro se relaciona con la precipitación y la evapotranspiración potencial. La precipitación anual aumenta desde $300 \mathrm{~mm}$ en la Depresión del Ebro hasta $1700 \mathrm{~mm}$ en la zona subalpina, y la evapotranspiración potencial disminuye desde 920 a $650 \mathrm{~mm}$. Sin embargo, en el alto Pirineo es fre cuente la existencia de meses con balance hídrico negativo. Para un perio do de 6 años (1994-1999) el balance hídrico potencial del suelo se calcu ló sobre la base de las propiedades físicas del suelo y de datos climáticos diarios. Los resultados muestran varios periodos con muy bajo contenido de agua disponible para las plantas en todas las áreas estudiadas, llegan do a 8 meses en la Depresión central del Ebro y 2 semanas en la alta mon taña. Además del pastoreo y la erosión del suelo, la limitación de agua dis ponible es la prinicpal razón de una sucesión vegetal lenta en los campos abandonados. 
Key-words: Soil water balance, Precipitation distribution, Physical soil properties, Abandoned fields, Pyrenees, Ebro Depression.

Palabras clave: Balance hídrico del suelo, Distribución de la precipitación, Propiedades físicas del suelo, Campos abandonados, Pirineos, Depresión del Ebro.

\section{Introduction}

The interest in water balance of Mediterranean countries is very high since presentday water shortages are endemic throughout this region (Kerkides et al., 1996; Milliman et al., 1992). For Aragón Cuadrat (1995) has calculated the potential evapotranspiration, the climatic water balance and the soil water balance by the method of Thornthwaite and Mather $(1955,1957)$. The calculation is based on long term mean values and shows a large deficit in the Inner Ebro Basin and a large surplus in the High Pyrenees. The objective of this study is to get a more detailed picture of the soil water budget on abandoned fields during the investigation period of the EPRODESERT project. A first step was to investigate the distribution of precipitation during the investigation period (1994-1999). The second step was the calculation of the soil water budget in daily intervals using a simple calculation method.

\section{Material and Methods}

\subsection{Precipitation}

Monthly and yearly precipitation values were taken from nearby climatic stations. The values were subdivided into five classes on the basis of precipitation measurements during 58 years from 1941 to 1999 . For each test area the distribution of precipitation was fitted for each month and year by a Weibull distribution. The probability density function is given by:

$$
f(x)=\frac{c}{b}\left(\frac{x-a}{b}\right)^{c-1} \cdot \exp \left\{-\left(\frac{x-a}{b}\right)^{c}\right\} \quad x>a
$$

The distribution function is given by:

$$
F(x)=1-\exp \left\{-\left(\frac{x-a}{b}\right)^{c}\right\} \quad x>a
$$

The parameters a, b and c were calculated by the Maximum Likelihood Method. The five classes were subdivided by the 20,40, 60 and 80 percentile of the fitted Weibull distribution (Schönwiese 2001: 85ff).

\subsection{Potential Evapotranspiration}

The potential evapotranspiration was calculated in daily intervals for the investigation period (1994-1999) by the method of Hargreaves and Samani $(1982,1985)$ as only thermopluviometric data were available. 


$$
P E T=0.0023 R_{a} \sqrt{\left(T_{\max }-T_{\min }\right)} \cdot T+17,8
$$

$\begin{array}{ll}\text { PET } & \text { potential evapotranspiration } \\ \mathrm{R}_{\mathrm{a}} & \text { solar irradiation (transformed into } \mathrm{mm} \mathrm{d}^{-1} \text { ) } \\ \mathrm{T}_{\max } & \text { daily maximum temperature } \\ \mathrm{T}_{\min } & \text { daily minimum temperature } \\ \mathrm{T} & \text { daily mean temperature }\end{array}$

\subsection{Physical Soil Properties}

In each test area physical properties of two characteristic soil profiles were investigated. For a better comparability of the test areas, the presented data refer to the upper $60 \mathrm{~cm}$ of the soil, which is the major rooting zone on abandoned fields. The soil water retention characteristics were measured on undisturbed core samples with the original pore size distribution for each horizon. From the water retention curve, the saturation capacity (SC), field capacity (FC) and permanent wilting point (PWP) were derived.

\subsection{Soil Water Balance}

The soil water balance was calculated in daily intervals by the method of Pfau (1966). Basis for the calculation is the simple equation:

$\mathrm{P}=\mathrm{AET}+\cap \mathrm{AW}+\mathrm{S}$

P precipitation $(\mathrm{mm} / \mathrm{d})$

AET actual evapotranspiration $(\mathrm{mm} / \mathrm{d})$

$\cap \mathrm{AW}$ change of soil water content $(\mathrm{mm} / \mathrm{d})$

S surplus water

The following assumptions are made:

1. Every precipitation above potential evapotranspiration enters the soil and no surface runoff occures.

2. The soil retains a maximum water amount at field capacity (FC), beyond which the moisture surplus is accumulated and deep percolation takes place. The available water capacity is given by the expression:

$A W C=D_{60}\left(\Theta_{F C}-\Theta_{P W P}\right)$

AWC available water capacity 


$$
\begin{aligned}
& \mathrm{D}_{60} \quad \text { rooting depth (in this study } 60 \mathrm{~cm} \text { ) } \\
& \Theta F C \quad \text { water content at field capacity } \\
& \text { @PwP water content at permanent wilting point }
\end{aligned}
$$

3. Output factors of the soil water storage system are actual evapotranspiration and deep percolation. In this study the soil moisture extraction function by Pfau (1966) was used. For periods with P < PET:

$$
A W_{i}=\frac{A W_{i-1}}{e^{\frac{P-P E T}{A W C}}}
$$

$\mathrm{AW}_{\mathrm{i}} \quad$ available water at day $_{\mathrm{i}}$

$\mathrm{AW}_{\mathrm{i}-1}$ available water at the day before

e $\quad 2,718282$

P-PET demand of potential evapotranspiration

AWC available water capacity

4. The available water (AW) of the current day is dependent on the soil moisture content of the previous day, the demand of the potential evapotranspiration and the available water capacity (AWC). This calculation is very close to the original by Thornthwait and Mather $(1955,1957)$ and gives an adequate approximation for clay rich soils (Dunne and Leopold 1995: 144).

5. Drainage (deep percolation) is considered to take place when precipitation exceeds potential evapotranspiration after the soil moisture storage reaches field capacity. It is assumed that only a certain percentage of the total quantity of surplus water will run off on any day. The remaining percentage will be held as gravitational water storage and made available for runoff on the following day. The percentage of surplus water lost each day depends on the soil type, structure and the depth of the soil layer (Thornthwaite and Mather 1957). In this study a simple relationship between the percentage of large pores and the percentage of water loss by gravitation was used.

\section{Test Areas}

The five EPRODESERT test areas are situated along a strong topographic and climatic gradient (Figure 1) from perhumid climate in the High Pyrenees to a semi-arid climate in the Central Ebro Basin (Ries et al., 1997).

Only $7 \mathrm{~km}$ from the French border the test area Aísa is situated 1700m a.s.1., in a subalpine environment, in the Flysch zone of the Sierras Interiores. Both soil profiles (5a, Humic Dystrocryept; 5b, Oxyaquic Haplocryalf ) (Tab. 1) are developed in weathered Flysch and influenced by solifluction. The upper $40 \mathrm{~cm}$ from profile $5 \mathrm{~b}$ are part of slipped slope (Blaike). 


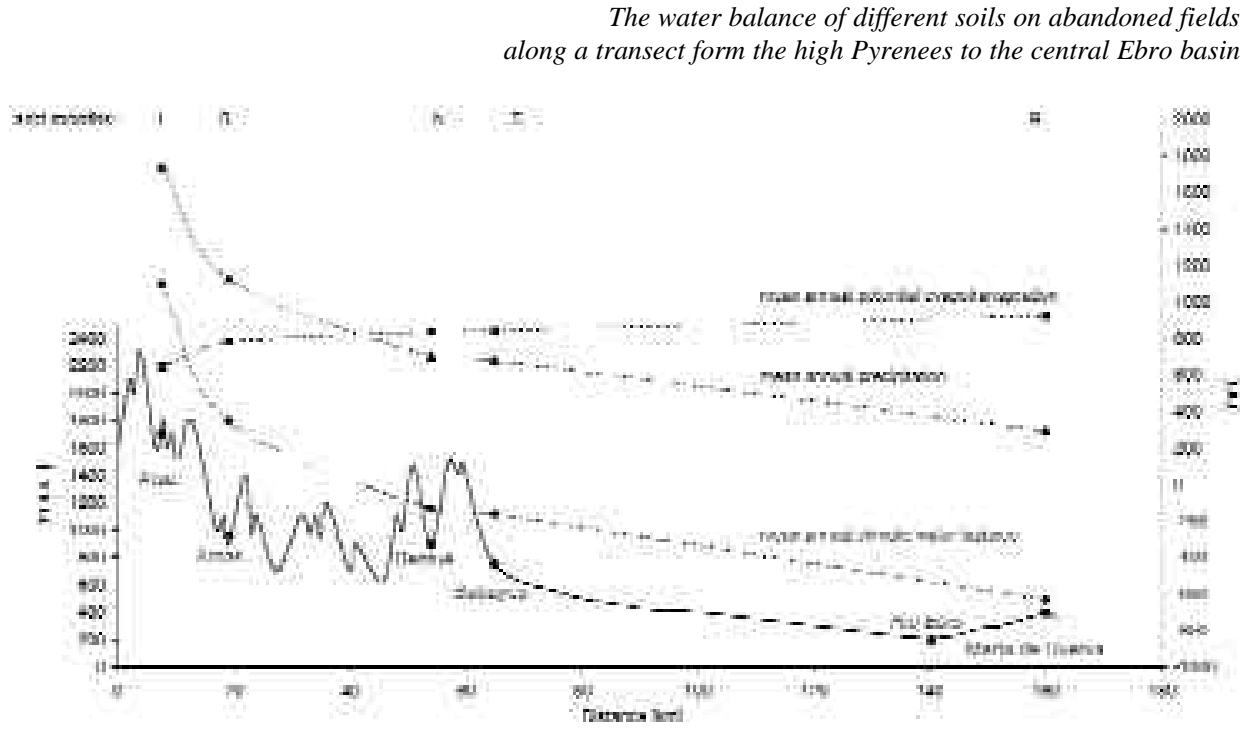

Figure 1: Transect from the High Pyrenees to the Inner Ebro Basin. Mean annual precipitation (1941-1999), mean annual potential evapotranspiration (1994-1999), calculated after Hargreaves and Samani (1985), mean annual climatic water balance and the average number of arid months for the five EPRODESERT test areas.

The second test area (Arnas) is located in the Central Pyrenees, in the montane altitude zone, $1000 \mathrm{~m}$ a.s.l. Geologically the area is dominated by Eocene clay-, marl- and sandstone of the Sierras Interiores. Both soil profiles (4a, Oxyaquic Vertic Haplustalf; $4 \mathrm{~b}$, Aquic Calciustept) are developed in an old landslide. Profile $4 \mathrm{~b}$ is situated in a slope position where erosion processes are dominant, while profile $4 \mathrm{a}$ is characterised by accumulation processes.

Bentué, the third test area, is situated in the central part of the Pre-Pyrenees, $1000 \mathrm{~m}$ a.s.l. The valley is developed in Eocene marine sediments, so called 'blue marls'because of their blue colour. Soil profile 3a (Lithic Xerorthent) is a strongly eroded profile, the lower $30 \mathrm{~cm}$ are part of the poorly weathered marls. Soil profile $3 \mathrm{~b}$ (Inceptic Haplustalf) is developed in a alluvial fan above strongly weathered marls.

At the foothills of the Pre-Pyrenees the test area Sabayés is situated $750 \mathrm{~m}$ a.s.1.. In this area Cretaceous limestone, dolomite, marls and Eocene limestone are dominant. Both soil profiles (2a, Haplic Calcixerept; 2b, Calcixerollic Xerochrept) are located on a large rotational landslide.

The test area María de Huerva is situated in the Inner Ebro Basin and geologically dominated by Miocene gypsum, marl and clay series. Soil profile 1a (Leptic Haplogypsid) is developed in strongly weathered Tertiary layers, soil profile $1 \mathrm{~b}$ (Leptic Haplogypsid) is developed in a Holocene alluvial fill.

The average precipitation along the transect decreases from over $1700 \mathrm{~mm}$ in the High Pyrenees to only $300 \mathrm{~mm}$ in the Inner Ebro Basin (Figure 1). The potential evapo- 
transpiration increases from $650 \mathrm{~mm}$ to more than $900 \mathrm{~mm}$. The climatic water balance is positive in the High and Central Pyrenees, with only 1 to 3 arid months. But already in the central Pre-Pyrenees (Bentué), the annual climatic water balance is negative with five arid months. The water deficit increases up to $650 \mathrm{~mm}$ in María de Huerva with 9 arid months. This climatic gradient within a distance of only $150 \mathrm{~km}$ is unique in Europe.

\section{Results}

\subsection{Precipitation Distribution (1994 - 1999)}

The precipitation amounts vary not only within the different years but also sometimes within the five test areas. However, in several years wet or dry periods can be observed throughout all test areas. For example in 1994 the yearly precipitation amount was very low in María de Huerva (MDH) and high in Aísa (AIS), but during the summer period (Jun-August) the precipitation amounts are low and very low in all five test areas. In 1995 the situation was even dryer, but again in Aísa the yearly precipitation sum was high. 1996 and 1997 were wet years with high precipitation amounts especially during the winter and summer months. 1998 again was a very dry year with only few months with high precipitation amounts. In 1999, months with very high precipitation alternate with months with low precipitation amounts. The over all the investigation period includes many different precipitation distributions. Very dry years, respectively very dry summers alternate with very wet conditions.

\subsection{Physical Soil Properties}

The saturation capacity (SC) varies between $184.1 \mathrm{~mm}$ in the strongly eroded soil profile in Bentué and over $300 \mathrm{~mm}$ in Aísa. Noticeable is the low air capacity (AC) in both profiles in Arnas (27.6 and $33.5 \mathrm{~mm}$ ), while the soils in Aísa have the highest air capacity. The water content at field capacity (FC) varies between $128 \mathrm{~mm}$ in profile $3 \mathrm{a}$

Table 1: physical soil properties $(\mathrm{mm} / 60 \mathrm{~cm})$ of 10 soil profiles in the EPRODESERT test areas.

\begin{tabular}{|c|c|c|c|c|c|c|}
\hline test area & soil & No. & SC & $\mathrm{AC}$ & FC & PWP \\
\hline & & & \multicolumn{4}{|c|}{$[\mathrm{mm}]$} \\
\hline \multirow[t]{2}{*}{ Aísa } & Humic Dystrocryept & $5 \mathrm{a}$ & 362.2 & 126.3 & 235.9 & 144.7 \\
\hline & Oxyaquic Haplocryalf & $5 b$ & 301.3 & 78.7 & 222.7 & 159.3 \\
\hline \multirow[t]{2}{*}{ Arnas } & Oxyaquic Vertic Haplustalf & $4^{\circ}$ & 250.7 & 33.5 & 217.4 & 128.3 \\
\hline & Aquic Calciustept & $4 b$ & 208.6 & 27.6 & 181.2 & 108.0 \\
\hline \multirow[t]{2}{*}{ Bentué } & Inceptic Haplustalf & $3 b$ & 247.3 & 74.8 & 172.6 & 96.4 \\
\hline & Lithic Xerorthent & $3 a$ & 184.1 & 56.0 & 128.1 & 81.1 \\
\hline \multirow[t]{2}{*}{ Sabayés } & Calcixerollic Xerochrept & $2 b$ & 226.0 & 70.9 & 155.1 & 92.8 \\
\hline & Haplic Calcixerept & $2 \mathrm{a}$ & 243.5 & 60.8 & 182.7 & 102.4 \\
\hline María de & Leptic Haplogypsid & $1 \mathrm{a}$ & 267.5 & 53.9 & 213.6 & 108.6 \\
\hline Huerva & Leptic Haplogypsid & $1 b$ & 261.0 & 81.5 & 179.5 & 110.0 \\
\hline
\end{tabular}




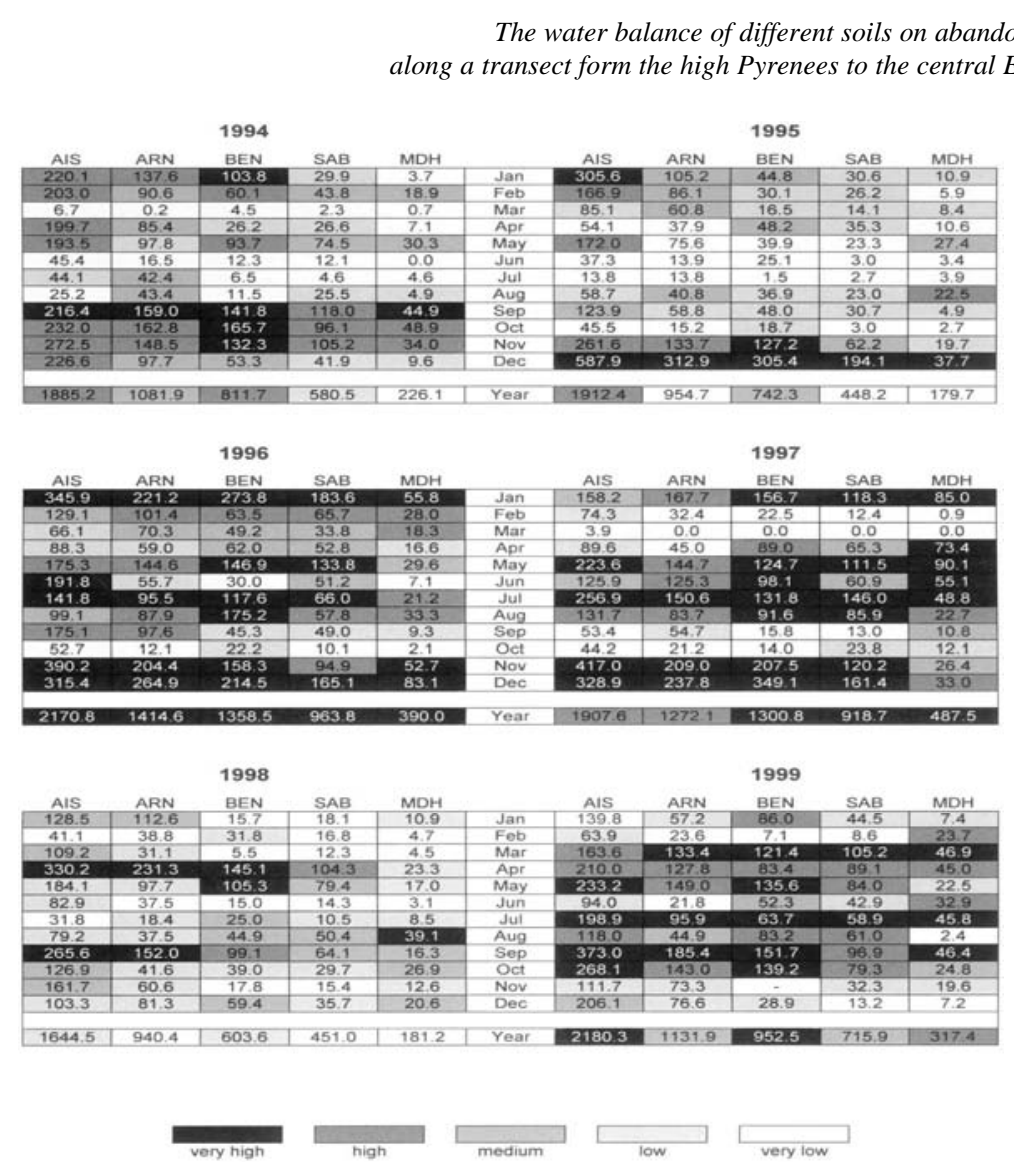

Figure 2: Precipitation during the investigation period (1994-1999) in the five EPRODESERT test areas.

(Bentué) and $236 \mathrm{~mm}$ in profile $5 \mathrm{~b}$ Aísa. Due to a high clay content the water content at permanent wilting point is very high in all test areas.

Because of the high water content at permanent wilting point together with relatively low water content at field capacity, the available water capacity (AWC) according to the German classification system (Arbeitsgemeinschaft Boden 1994) is only medium or low for all profiles. It varies between $48 \mathrm{~mm}$ in Bentué and $105 \mathrm{~mm}$ in María (Figure 3).

\subsection{Soil Water Balance}

Figure 4 shows the calculated soil moisture curve of the upper $60 \mathrm{~cm}$ for the period from 1994 to 1999 of soil profile 3b in Bentué (central Pre-Pyrenees). The x axis represents the time. On the y axis the daily precipitation (black) and the monthly precipitation (grey) are shown. Additionally the different water holding properties of the soil profile are given: the upper dashed black line shows the saturation capacity, the dashed line in the middle shows soil moisture at field capacity and the lower dashed line shows soil 


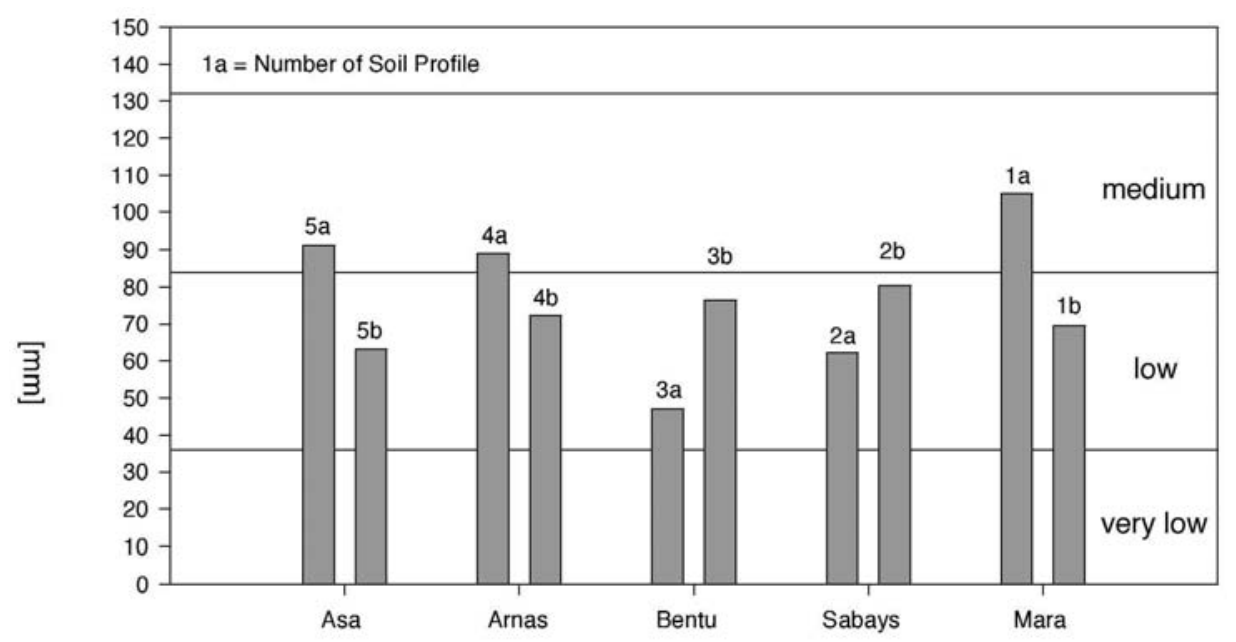

Figure 3: Available water capacity $(\mathrm{mm} / 60 \mathrm{~cm})$ of 10 soil profiles in the EPRODESERT test areas.

moisture at permanent wilting point. The two short-dashed dark grey lines between permanent wilting point and field capacity represent 20 and 80 percent of the available soil water capacity.

As with precipitation, soil water content was subdivided into five classes. It is very low when the available soil water content is 0 , low when the available soil water content is below $20 \%$ of the available soil water capacity, medium between 20 and $80 \%$, high above $80 \%$ of the available soil water capacity and very high when soil moisture content is above field capacity.

In this example from Bentué, long periods with a plant available water content below $20 \%$ of the available water capacity occur in July and August 1994 and in June, July and August 1995. In 1996 very high precipitation in May, July and August leads only to a very short dry period in the second half of June. In 1997 no periods with a low content of plant available water can be observed. In 1998 and 1999 again some periods with a low water content occur.

The black circles show the measured soil water content. The measured values are very close to the calculated values in spring 1997 and 1998 and in autumn 1998. In summer 1998 the measured soil water content is much lower than the calculated.

Figure 5 shows the summary of the soil water content of all 10 soil profiles. It is not very astonishing that the dark colours (high water content) decrease from the soil profiles in the High Pyrenees to the Inner Ebro Basin and light colours (low water content) increase. In the years with very dry summers (1994, 1995 and 1998) dry periods occur in all test areas. They last from 5 days in Aísa (High Pyrenees) (1998, profile 5b) up to 8 


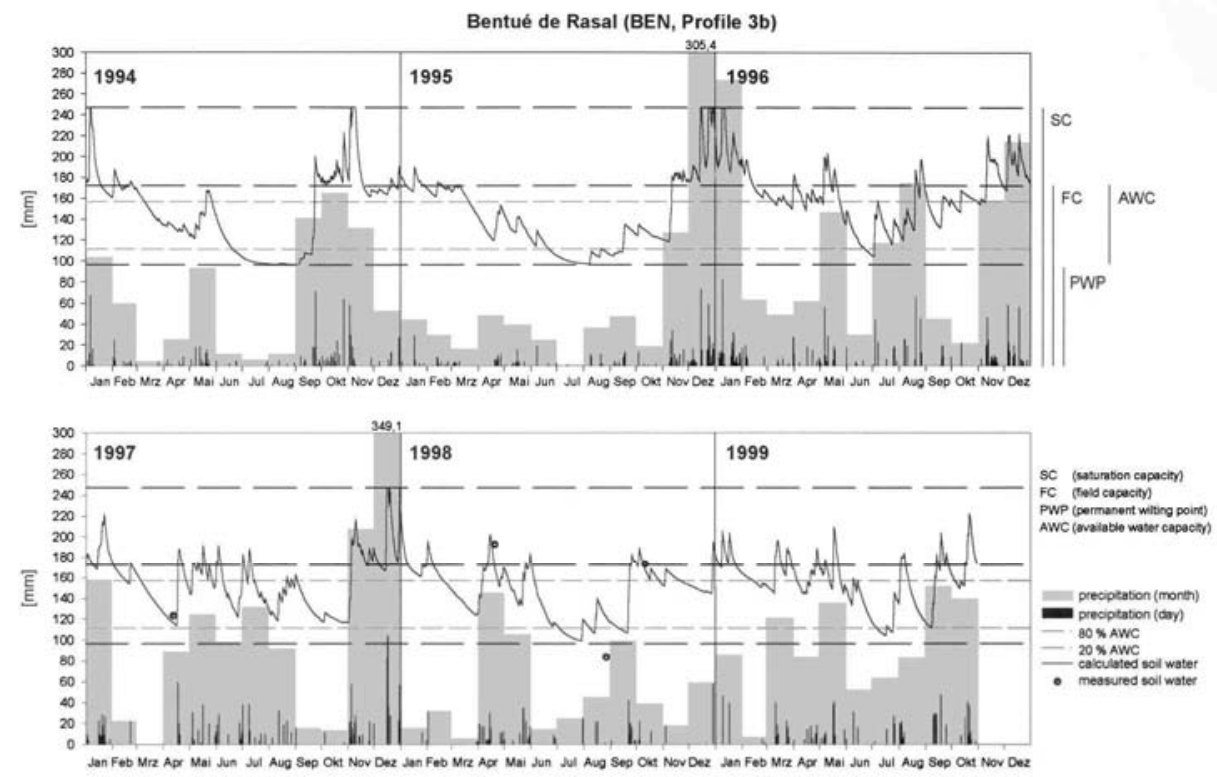

Figure 4: Calculated soil water curve (upper $60 \mathrm{~cm}$ ) of The Inceptic Haplustalf (soil profile $3 \mathrm{~b}$ ) in Bentué (central Pre-Pyrenees)

months in the semi-arid Ebro Basin (1995, profile 1b). In years with a high and very high precipitation amount and especially with high precipitation amounts in summer (1996 and 1997), only in Bentué, Sabayés and María de Huerva periods with a low content of soil water can be observed. They last from 2 weeks in Bentué to more than 3 months in María de Huerva (1997). Especially in María de Huerva the period with a low content of soil water is very late this year due to a very moist spring and summer. In 1999, in all test areas apart from Aísa considerably dry periods can be observed; in María de Huerva they are short compared to the years before, interrupted by periods of medium soil water content.

\section{Discussion}

The precipitation distribution has a high variability in all test areas. The combination of the physical soil properties (especially available water capacity) with the precipitation and potential evapotranspiration data shows in all test areas the probability of considerable periods with a available water content below $20 \%$ of the available water capacity. This is not very surprising in a semi-arid environment like the Inner Ebro Basin. But in a mountainous region low water content over a longer time period can seriously affect the vegetation succession. In every test area at least one soil profile has a low available water capacity only, thus dry periods coincide with a low storage capacity in the upper $60 \mathrm{~cm}$ of the soil profile. 


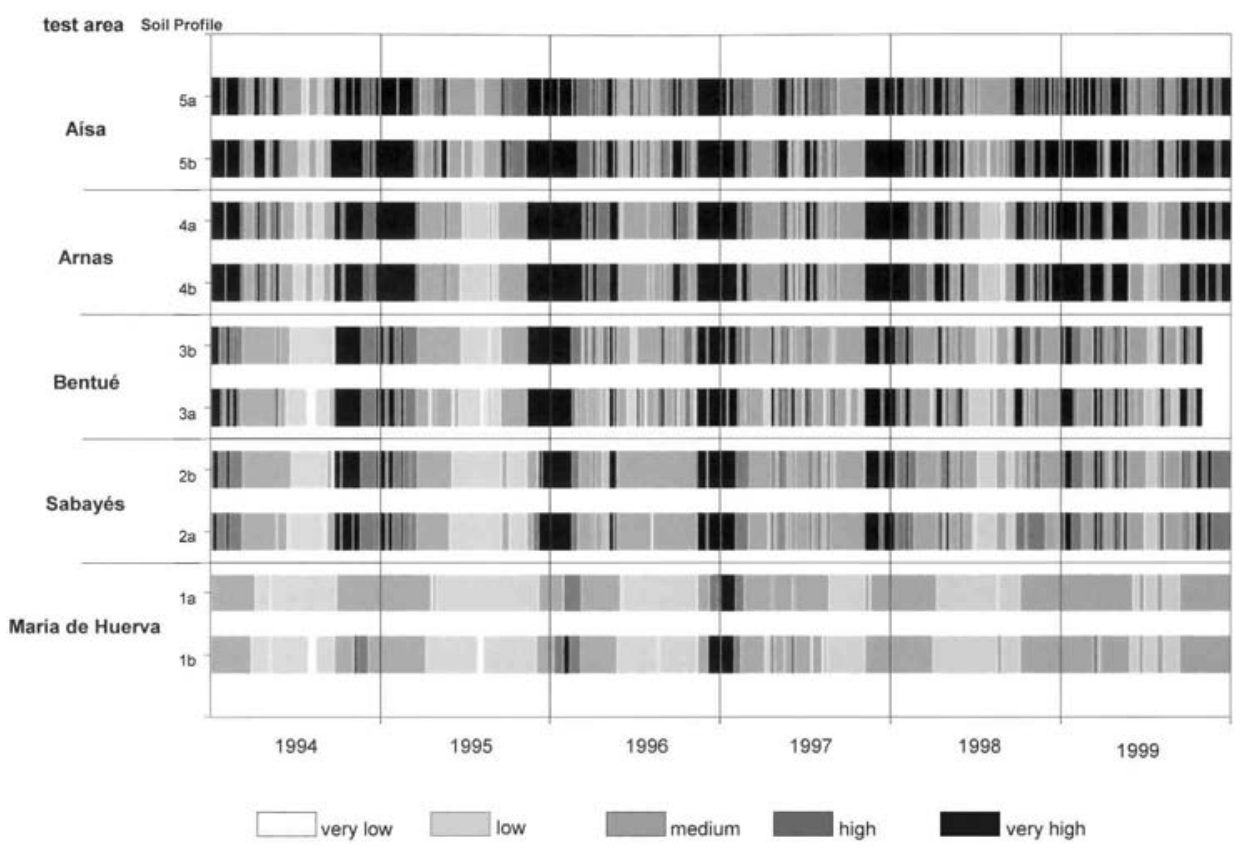

Figure 5: Calculated soil water balance of 10 soil profiles in the EPRODESERT test areas.

The example of Bentue (Figure 4) shows that the real soil water content can fall below the permanent wilting point. This was observed in all test areas in summer 1998, except Aísa. The water extraction function by Pfau (1966) considers only the available water capacity, thus the calculated soil water content can not be below the permanent wilting point. This calculation problem gets more important with long lasting dry periods. Therefore the soil water problem can be even more serious than this study shows.

\section{Conclusions}

1. A low content of soil moisture in the major rooting zone can be observed for several periods in all test areas from the Inner Ebro Basin to the High Pyrenees. They last from little less than one week in the High Pyrenees to up to 8 months in the Inner Ebro Basin.

2. The calculation of soil water content in daily intervals gives a detailed picture of soil water conditions. During long lasting dry periods the calculation overestimates the real soil water content, because the calculation excludes the possibility of water content below permanent wilting point.

3. In this study only climatic data and soil water storage properties are taken into account. It is not considered that the amount of water which enters the soil is 
reduced by surface runoff or interception. Thus, the problem of low soil moisture contents could be even more serious than the data of this study show.

4. It is very important to protect the soils from further soil erosion and to preserve a high infiltration rate to guarantee a minimum of plant available water on abandoned fields for vegetation succession during long lasting and recurring dry periods.

\section{Acknowledgements}

This work was carried out as part of the EPRODESERT project funded by the Deutsche Forschungsgemeinschaft (No. Ri 835/1-3: “Landnutzungswandel, Erosion und Desertifikation in Nordostspanien"). We thank Dr. Manuel Seeger and Christian Frevel for assistance in the field and for the permission for using their data.

\section{References}

Arbeitsgemeinschaft Boden (1994). Bodenkundliche Kartieranleitung, 392 pp., Stuttgart.

Cuadrat J. M. (1995). Evapotranspiración y balance de humedad. Atlas de Geografía de Aragón, 1.2.7., Zaragoza.

Dunne, T. and Leopold, B. L. (1995). Water in Environmental Planning. Freeman, 818 pp., San Francisco.

Hargreaves, G. H. and Samani, Z. A. (1982). Estimating potential evapotranspiration. ASCE, Journal of Irrigation and Drainage, 108: 225-230.

Hargreaves, G. H. and Samani, Z. A. (1985). Reference crop evaporation from temperature. Applied Engineering in Agriculture, 1 (2): 96-99.

Kerkides, P., Michalopoulou, H., Papaioannou, G. and Pollatou, R. (1996). Water balance estimates over Greece. Agricultural Water Management, 32: 85-104.

Milliman, J. D., Jeftic, L. and Sestini, G. (1992). The Mediterranean Sea and climatic change - an overview. In: Jeftic, L., Milliman, J. D., and Sestini (eds.): Climate Change and the Mediterranean, pp. 1-14, London.

Ries, J. B., Seeger, M. and Marzolff, I. (1997). El proyecto EPRODESERT. Cambios de uso del suelo y morfodinámica en el Nordeste de España. Geographicalia, 35: 205-225.

Thornthwaite, C. W. and Mather, J. R. (1955). The water balance. Publications in Climatology, 8: 1-86.

Thornthwaite, C. W. and Mather, J. R. (1957). Instructions and tables for computing potential evapotranspiration and water balance. Publications in Climatology, 10: 243-311.

Pfau, R. (1966). Ein Beitrag zur Frage des Wasserhaushaltes und der Beregnungsbedürftigkeit landwirtschaftlich genutzter Böden im Raume der Europäischen Wirtschaftsgemeinschaft. Meteorologische Rundschau, 19: 33-46.

Schönwiese, C. D. (2000). Praktische Statistik für Meteorologen und Geowissenschaftler. 292 pp., Berlin. 